\title{
Gambaran Jumlah Eosinofil Darah Tepi Penderita Asma Bronkial di Bangsal Paru RSUP Dr. M. Djamil Padang
}

\author{
Demas Nico M. Manurung, Ellyza Nasrul, Irvan Medison
}

\begin{abstract}
Abstrak
Asma merupakan penyakit gangguan inflamasi kronis saluran pernapasan dengan banyak sel serta elemen seluler yang berperan. Asma dihubungkan dengan hiperresponsif bronkus, keterbatasan aliran udara dan gejala pernapasan yang bersifat reversibel. Salah satu sel yang diketahui berperan besar dalam patogenesis asma adalah eosinofil. Eosinofil melepaskan berbagai mediator seperti Major Basic Protein, Eosinophil Cationic Protein, peroksidase eosinofil, leukotrien C4, serta Platelet-Activating Faktor yang akan merusak epitel saluran napas serta menyebabkan peradangan. Penelitian ini dilaksanakan pada bulan Januari sampai Desember 2012 di Bagian Rekam Medik RSUP Dr. M. Djamil Padang dengan tujuan untuk melihat gambaran jumlah eosinofil darah tepi pada penderita asma bronkial yang dirawat inap. Penelitian yang dilakukan bersifat deskriptif dengan tinjauan retrospektif. Penelitian dilakukan dengan melihat data rekam medis penderita asma bronkial yang dirawat inap di Bangsal Paru RSUP Dr. M. Djamil Padang periode Januari 2010-Desember 2012. Dalam periode dua tahun tersebut, diperoleh 18 sampel yang digunakan pada penelitian ini. Hasil yang diperoleh ialah 4 penderita memiliki jumlah eosinofil darah tepi normal (40400/mm3) (22,22\%) dan 14 penderita memiliki jumlah eosinofil darah tepi dibawah normal $(<40 / \mathrm{mm} 3)(77,78 \%)$. Tidak ditemukan penderita asma dengan eosinofilia $(>400 / \mathrm{mm} 3)$. Jumlah eosinofil darah tepi pada penderita asma bronkial lebih banyak dibawah normal.
\end{abstract}

Kata kunci: Asma Bronkial, Eosinofil

\begin{abstract}
Asthma is a chronic inflammatory disorder of the airways in which many cells and cellular elements play a role. Asthma is associated with hyperresponsif bronchi, airflow limitation, and respiratory symptomps that are reversible. One of cells which is known to play a major role in asthma pathogenesis is eosinophil. Eosinophil release a variety of mediators such as Major Basic Protein, Eosinophil Cationic Protein, Eosinophil Peroxidase, Leukotriene C4, and Platelet Activating Factor that will damage airway epithelium and cause inflammation. The research was conducted in January 2012 through December 2012 at Medical Records Department of RSUP Dr. M. Djamil Padang aiming to see the overview of peripheral blood eosinophil number in patient with bronchial asthma who are hospitalized. The research conducted is using descriptive retrospective review. The study is done by looking medical record data of bronchial asthma patient hospitalized in pulmonary ward of RSUP Dr. M. Djamil Padang in the period of January 2010-December 2012. In the two year period, there are 18 patients which are used in the study. The results are 4 patients had normal peripheral blood eosinophil number (40-400/mm3)(22,22\%), 14 patients had low peripheral blood eosinophil number $(<40 / \mathrm{mm} 3)(77,78 \%)$. There is no patient with eosinophilia $(>400 / \mathrm{mm} 3)$. Peripheral blood eosinophil number in bronchial asthma patient is mostly low.
\end{abstract}

Keywords: Bronchial Asthma, Eosinophil

Affiliasi penulis : Demas Nico M. Manurung,

Korespondensi : Fakultas Kedokteran Universitas Andalas, email : nico_bhatubim@yahoo.com Telp: 0751-79502077

\section{PENDAHULUAN}

Eosinofil memiliki diameter kira-kira $8 \mu \mathrm{m}$ dengan inti sel biasanya berupa bilobus, kadang dapat ditemui tiga atau lebih lobus. Eosinofil ditandai oleh granul kristaloid besar yang dikenal sebagai granul spesifik atau sekunder, berwarna merah terang setelah pewarnaan dengan zat pewarna asam seperti eosin pada mikroskop cahaya. ${ }^{1}$

Pembentukan eosinofil terjadi di sum-sum tulang yang merupakan tempat terjadinya hematopoiesis. Pematangan granulosit ditandai dengan sintesis protein oleh retikulum endoplasma kasar dan kompleks Golgi dalam dua tahap. Tahap pertama, protein yang dihasilkan akan dikemas dalam granul azurofilik. Pada tahap kedua, protein yang dihasilkan dikemas dalam granul spesifik yang digunakan untuk berbagai aktivitas. ${ }^{2}$

Diferensiasi eosinofil terjadi akibat pengaruh dari $T$-cell derived eosinophilopoietic cytokines dan growth factor yaitu interleukin-5 (IL-5), interleukin-3
(IL-3), dan Granulocyte/Macrophage-Colony Stimulating Factor (GM-CSF). IL-3 dan GM-CSF memiliki peran dalam hematopoiesis turunan sel darah yang lain, sedangkan IL-5 bersifat lebih spesifik terhadap perkembangan dari eosinofil. ${ }^{3}$

Eosinofil memiliki fungsi yang dijalankan dalam peran yang berbeda, yaitu dalam peran efektor dan peran kolaboratif. Eosinofil memiliki kemampuan melakukan fagositosis dan eliminasi bakteri dan mikroorganisme lainnya. Eosinofil menghasilkan dua mediator lipid yang terlibat dalam penyakit alergi (termasuk asma) yaitu leukotrien C4 dan PlateletActivating Factor (PAF). Mediator tersebut menyebabkan kontraksi otot polos saluran napas, meningkatkan produksi mukus, meningkatkan permeabilitas vaskular, dan membantu infiltrasi eosinofil dan neutrofil. Eosinofil diyakini memiliki kemampuan untuk bekerja sama dengan limfosit dan sel imun serta mesenkimal lain yang berperan dalam kesehatan dan penyakit, seperti kemampuan berperan sebagai antigen presenting cell (APC). ${ }^{4}$

Menurut Global Initiative for Asthma (GINA) dalam Global Strategy for Asthma Management and Prevention, asma merupakan penyakit infamasi kronik 
saluran napas dengan banyak sel serta elemen seluler yang berperan, serta berhubungan dengan hiperresponsivitas jalan napas dengan manifestasi berupa episode berulang dari mengi, sesak napas, rasa berat di dada, dan batuk terutama malam atau dini hari dan sering bersifat reversibel secara spontan atau dengan pengobatan. ${ }^{5}$

Perkembangan asma ditimbulkan oleh interaks antara faktor pejamu (terutama genetik) dan pajanan dengan lingkungan yang terjadi dalam perkembangan sistem imun. Pajanan lingkungan mencakup faktor pejamu seperti genetik, diet-obesitas, dan jenis kelamin. Laki-laki memiliki risiko menderita asma lebih tinggi daripada perempuan sebelum usia 14 tahun sementara pada usia lebih tua, prevalensi asma sama antara laki-laki dan perempuan. Pada dewasa, prevalensi perempuan lebih besar dibanding laki-laki. Faktor lingkungan yang juga berperan mencakup pajanan alergen, infeksi, pajanan asap rokok dan lingkungan pekerjaan. ${ }^{6}$

Hipersensitivitas tipe 1 menjadi dasar dalam patogenesis asma ekstrinsik. Sensitisasi sel T naïve mengawali patogenesis asma ekstrinsik. Alergen yang masuk ke dalam tubuh akan diolah oleh Antigen Presenting Cell (APC) yaitu sel dendritik dan makrofag, kemudian dipresentasikan kepada sel $T$ naïve (Th0). Selanjutnya sel $\mathrm{T}$ naïve akan berkembang menjadi Th 1 atau Th2 tergantung dari sifat antigen, karakteristik APC, dan konsentrasi sitokin lokal. Sumber sitokin yang mempengaruhi diferensiasi sel T naïve adalah APC (khususnya sel dendritik), sel epitel dan otot saluran napas, sel $\mathrm{T}$, eosinofil, sel mast, makrofag, fibroblast. ${ }^{7-9}$

Stimulasi antigen yang berasal dari alergen dan antigen ekstraselular menyebabkan terbentuknya IL-4 dengan konsentrasi tinggi sehingga sel $\mathrm{T}$ naïve berdiferensiasi menjadi sel Th2. Interleukin 4 berperan mengahambat terbentuknya sel Th1. ${ }^{10}$

Sel Th2 akan menyekresikan sitokin seperti Interleukin 4, 5, dan 13 (IL-4, IL-5, IL-13). Interleukin 4 dan 13 menyebabkan sel $B$ berdiferensiasi menjadi sel Plasma yang memroduksi lgE. Interleukin 5 menyebabkan terjadinya eosinofilopoiesis dan aktivasi eosinofil. Antibodi lgE akan berikatan dengan reseptor Fc pada sel mast dan basofil. 8,10

Apabil terjadi pemaparan ulang dengan alergen, maka alergen tersebut akan berikatan dengan 2 molekul IgE pada permukaan sel membentuk jembatan yang disebut dengan crosslinking. Segera setelah sinyal awal akibat crosslinking, terjadi serangkaian reaksi biokimia intraselular secara berurutan menyerupai kaskade, dimulai dengan aktivasi enzim metiltransferase dan serine esterase, diikuti perombakan fosfatidilinositol menjadi inositol trifosfat (IP3), pembentukan diasilgliserol dan peningkatan ion $\mathrm{Ca}^{++}$intrasitoplasmik. Reaksi kimia ini menyebabkan terbentuknya zat yang memudahkan fusi membran granula sehingga terjadi degranulasi. ${ }^{11}$

Serangan asma ekstrinsik memperlihatkan dua fase: fase awal, dimulai 30 hingga 60 menit setelah inhalasi antigen yang kemudian mereda, diikuti 4-8 jam kemudian oleh fase lanjut. Pengaktifan awal sel mast terjadi di permukaan mukosa, mengakibatkan pelepasan mediator yang membuka taut-erat (tight junction) antar sel epitel sehingga lebih banyak antigen dapat masuk dan berikatan dengan sel mast subepitel. Sel mast juga melepaskan mediator lain seperti Leukotrien $\mathrm{C}_{4}, \mathrm{D}_{4}$, dan $\mathrm{E}_{4}$, Prostaglandin $\mathrm{D}_{2}, \mathrm{E}_{2}$, dan F2a, Histamin, Platelet-activating factor, Triptase.
Reaksi awal ini diikuti oleh fase lanjut yang didominasi oleh leukosit seperti eosinofil, basofil, dan neutrofil. Eosinofil sangat penting dalam fase lanjut. Rekrutmen eosinofil ditunjang oleh kemotaksin yang dihasilkan sel mast. Sel epitel bronkus aktif, makrofag, dan otot polos jalan napas turut menghasilkan eotaksin yang dianggap sebagai kemotaksin paling poten. Selanjutnya eosinofil juga akan melepaskan berbagai mediator seperti MBP, ECP, peroksidase eosinofil, leukotrien $\mathrm{C}_{4}$, serta platelet-activating factor yang mempertahankan respon inflamasi lebih lanjut. ${ }^{12}$

Penelitian ini dilakukan dengan tujuan untuk mengetahui jumlah eosinofil darah tepi pada penderita asma bronkial yang dirawat inap di Bangsal Paru RSUP Dr. M. Djamil Padang periode Januari 2010 sampai Desember 2012.

\section{METODE}

Penelitian dilakukan bersifat deskriptif dengan tinjuan retrospektif di RSUP Dr. M. Djamil Padang pada bulan Januari sampai Desember 2012. Sampel penelitian adalah semua pasien dengan diagnosis akhir asma bronkial yang dirawat inap di Bangsal Paru RSUP Dr. M. Djamil Padang dari bulan Januari 2010 sampai Desember 2012 yang memenuhi kriteria yang ditetapkan. Data yang diperoleh diolah dan dikelompokkan secara manual dalam bentuk tabel distribusi frekuensi.

\section{HASIL DAN PEMBAHASAN}

Tabel 1. Karakteristik Data

\begin{tabular}{cc}
\hline Karakteristik & Jumlah \\
\hline Jenis Kelamin & $7(38,89 \%)$ \\
Laki-laki & $11(61,11 \%)$ \\
Perempuan & \\
Umur & $20-77\left(\right.$ rata $\left.^{2} 47,72\right)$ \\
& \\
Derajat Serangan Asma & $1(5,56 \%)$ \\
Ringan & $16(88,88 \%)$ \\
Sedang & $1(5,56 \%)$ \\
Berat &
\end{tabular}

Tabel 4.1 memperlihatkan bahwa terdapat 18 kasus asma bronkial yang memenuhi syarat dengan pasien laki-laki berjumlah 7 orang $(38,89 \%)$ dan perempuan berjumlah 11 orang $(61,11 \%)$. Perbandingan pasien laki-laki dan perempuan adalah 1: 1,57 .

Tabel 2. Gambaran Penderita Asma Bronkial Berdasarkan Kelompok Umur

\begin{tabular}{ccc}
\hline $\begin{array}{c}\text { Kelompok } \\
\text { umur }\end{array}$ & Frekuensi & $\begin{array}{c}\text { Persentase } \\
(\%)\end{array}$ \\
\hline $20-29$ & 3 & 16,67 \\
$30-39$ & 2 & 11,10 \\
$40-49$ & 5 & 27,78 \\
$50-59$ & 3 & 16,67 \\
$60-69$ & 4 & 22,23 \\
$70-79$ & 1 & 5,55 \\
\hline Total & 18 & 100 \\
\hline
\end{tabular}

Tabel 4.2 memperlihatkan bahwa angka kejadian serangan akut asma tertinggi adalah pada kelompok umur 40-49 tahun $(27,78 \%)$, diikuti oleh kelompok umur 60-69 tahun (22,23\%), umur 20-29 tahun (16,67\%) dan umur 50-59 tahun (16,67\%), umur 
30-39 tahun (11,10\%), dan umur 70-79 tahun (5,55\%). Penderita asma bronkial yang paling muda berumur 20 tahun dan paling tua berumur 77 tahun.

Tabel 3. Gambaran Jumlah Eosinofil Darah Tepi Penderita Asma Bronkial

\begin{tabular}{ccc}
\hline $\begin{array}{c}\text { Jumlah eosinofil } \\
\left(/ \mathrm{mm}^{3}\right)\end{array}$ & Frekuensi & $\begin{array}{c}\text { Persentase } \\
(\%)\end{array}$ \\
\hline$<40($ rendah) & 14 & 77,78 \\
$40-400$ (normal) & 4 & 22,22 \\
$>400$ (eosinofilia) & 0 & 0 \\
\hline Total & 18 & 100 \\
\hline
\end{tabular}

Berdasarkan tabel 4.3, didapatkan penderita asma dengan jumlah eosinofil normal $\left(40-400 / \mathrm{mm}^{3}\right)$ adalah 4 kasus $(22,22 \%)$, dan penderita dengan jumlah eosinofil dibawah normal $\left(<40 / \mathrm{mm}^{3}\right)$ adalah 14 kasus $(77,78 \%)$. Tidak ditemukan penderita asma bronkial dengan eosinofilia.

Tabel 4. Gambaran Jumlah Eosinofil Darah Tepi Berdasarkan Kelompok Umur

\begin{tabular}{ccccccc}
\hline $\begin{array}{c}\text { Kelompok } \\
\text { umur }\end{array}$ & \multicolumn{3}{c}{ Jumlah eosiniofil $\left(/ \mathrm{mm}^{3}\right)$} & \multicolumn{2}{c}{ Total } \\
\cline { 2 - 5 } & \multicolumn{2}{c}{$<40$} & \multicolumn{2}{c}{$40-400$} & \multicolumn{2}{c}{} \\
\cline { 2 - 6 } & $\mathrm{f}$ & $\%$ & $\mathrm{f}$ & $\%$ & $\mathrm{f}$ & $\%$ \\
\hline $20-29$ & 2 & 11,12 & 1 & 5,55 & 3 & 16,67 \\
$30-39$ & 1 & 5,55 & 1 & 5,55 & 2 & 11,10 \\
$40-49$ & 4 & 22,23 & 1 & 5,55 & 5 & 27,78 \\
$50-59$ & 2 & 11,12 & 1 & 5,55 & 3 & 16,67 \\
$60-69$ & 4 & 22,23 & 0 & 0 & 4 & 22,23 \\
$70-79$ & 1 & 5,55 & 0 & 0 & 1 & 5,55 \\
\hline Total & 14 & 77,80 & 4 & 22,20 & 18 & 100 \\
\hline
\end{tabular}

Dari tabel 4.4, didapatkan penderita asma dengan jumlah eosinofil dibawah normal $\left(<40 / \mathrm{mm}^{3}\right)$ berada pada kelompok umur 20 sampai 79 tahun. Jumlah eosinofil normal didapat pada pasien dengan kelompok umur 20 tahun sampai 59 tahun. Jumlah eosinofil dibawah normal lebih banyak ditemukan pada kelompok umur 40-49 dan 60-69 tahun (22,23\%). Tidak didapat penderita asma dengan eosinofilia $\left(>400 / \mathrm{mm}^{3}\right)$

Tabel 5. Gambaran Jumlah Eosinofil Darah Tepi Berdasarkan Jenis Kelamin

\begin{tabular}{lcccccc}
\hline \multirow{2}{*}{$\begin{array}{c}\text { Jenis } \\
\text { kelamin }\end{array}$} & \multicolumn{4}{c}{ Jumlah eosinofil $\left(/ \mathrm{mm}^{3}\right)$} & \multirow{2}{*}{ Total } \\
\cline { 2 - 5 } & \multicolumn{2}{c}{$<40$} & \multicolumn{2}{c}{$40-400$} & & \\
\cline { 2 - 6 } & $\mathrm{f}$ & $\%$ & $\mathrm{f}$ & $\%$ & $\mathrm{f}$ & $\%$ \\
\hline Laki-laki & 5 & 27,78 & 2 & 11,11 & 7 & 38,89 \\
Perempuan & 9 & 50 & 2 & 11,11 & 11 & 61,11 \\
\hline Total & 14 & 77,78 & 4 & 22,22 & 18 & 100 \\
\hline
\end{tabular}

Berdasarkan tabel 4.5, jumlah eosinofil rendah $(<40 / \mathrm{mm} 3)$ lebih banyak pada penderita asma bronkial dengan jenis kelamin perempuan (50\%), sementara untuk jumlah eosinofil normal (40$400 / \mathrm{mm} 3$ ) tidak terdapat perbedaan jumlah antara laki-laki dan perempuan $(11,11 \%)$.
Tabel 6. Gambaran Jumlah Eosinofil Darah Tepi Berdasarkan Derajat Serangan Asma

\begin{tabular}{|c|c|c|c|c|c|c|}
\hline \multirow{3}{*}{$\begin{array}{c}\text { Derajat } \\
\text { serangan } \\
\text { asma }\end{array}$} & \multicolumn{4}{|c|}{ Jumlah eosinofil $\left(/ \mathrm{mm}^{3}\right)$} & \multirow{2}{*}{\multicolumn{2}{|c|}{ Total }} \\
\hline & \multicolumn{2}{|c|}{$<40$} & \multicolumn{2}{|c|}{$40-400$} & & \\
\hline & $f$ & $\%$ & $f$ & $\%$ & $f$ & $\%$ \\
\hline Ringan & 1 & 5,56 & 0 & 0 & 1 & 5,56 \\
\hline Sedang & 13 & 72,22 & 3 & 16,66 & 16 & 88,88 \\
\hline Berat & 0 & 0 & 1 & 5,56 & 1 & 5,56 \\
\hline Total & 8 & 77,78 & 4 & 22,22 & 18 & 100 \\
\hline
\end{tabular}

Dari tabel 4.6, jumlah penderita asma bronkial dengan serangan asma sedang memiliki jumlah eosinofil darah tepi dibawah normal sebanyak 13 orang $(72,22 \%)$, sedangkan 3 orang memiliki jumlah eosinofil darah tepi normal $(16,66 \%)$. Penderita dengan derajat serangan ringan adalah 1 orang dengan eosinofil rendah $(5,56 \%)$ dan penderita dengan derajat serangan berat berjumlah 1 orang dengan jumlah eosinofil darah tepi normal (5,56\%).

Jenis kelamin merupakan salah satu faktor risiko asma bronkial. Pada tabel 4.1, didapatkan hasil bahwa kejadian asma bronkial di RSUP Dr. M. Djamil pada periode Januari 2010 sampai Desember 2012 lebih banyak terjadi pada perempuan dengan perbandingan laki-laki dan perempuan adalah 1:1,57. Hal ini sesuai dengan penelitian yang dilakukan Akinbami, dkk (2011) yang menyatakan bahwa perbandingan prevalensi asma antara laki-laki dan perempuan adalah 1:1,32. Selain itu, penelitian yang dilakukan Sihombing, dkk (2010) juga mendapatkan hasil serupa dimana perempuan $(51,5 \%)$ lebih banyak menderita asma dibanding laki-laki $(48,5 \%) .{ }^{13,14}$

Gambaran penderita asma bronkial berdasarkan umur yang diperoleh dalam penelitian ini adalah kelompok umur 40 sampai 49 (27,78\%) tahun paling banyak mengalami serangan akut asma. Menurut data National Health Interview Survey (NHIS)(2009), prevalensi asma tertinggi berada pada kelompok umur 5-14 tahun (11,2\%). Sementara Oemiati, dkk (2010) menemukan bahwa peningkatan persentase penduduk yang menderita asma berbanding lurus dengan usia, dengan persentase tertinggi pada usia di atas 75 tahun $(10,9 \%) .{ }^{15,16}$

Gambaran jumlah eosinofil penderita asma bronkial yang diperoleh dari penelitian ini memperlihatkan bahwa penderita asma terbanyak memiliki jumlah eosinofil rendah yaitu 14 orang $(77,78 \%)$, sementara sisanya memiliki jumlah eosinofil normal sebanyak 4 orang $(22,22 \%)$. Tidak ditemukan penderita dengan eosinofilia. Sementara berdasarkan kelompok umur, gambaran eosinofil yang diperoleh kelompok umur 20 sampai 70 tahun terdapat jumlah eosinofil darah tepi rendah dengan kasus terbanyak pada kelompok umur 40 sampai 49 tahun $(22,23 \%)$ dan 60 sampai 69 tahun $(22,23 \%)$ yang masingmasingnya berjumlah 4 orang. Untuk jumlah eosinofil normal terdapat pada kelompok umur 20 sampai 59 tahun.

Pada gambaran eosinofil berdasarkan jenis kelamin, hasil yang diperoleh pada penelitian ini adalah penderita dengan eosinofil rendah terbanyak dialami perempuan sebanyak 9 orang (50\%), sementara jumlah pasien laki-laki $(11,11 \%)$ dan perempuan $(11,11 \%)$ sama pada keadaan eosinofil normal yaitu 2 orang. Gambaran jumlah eosinofil berdasarkan derajat serangan akut yang didapat dalam penelitian ini memperlihatkan pasien dengan 
derajat serangan akut sedang lebih banyak memiliki jumlah eosinofil rendah $(72,22 \%)$, sementara 1 pasien $(5,56 \%)$ dengan derajat serangan akut ringan memiliki jumlah eosinofil rendah dan 1 pasien (5,56\%) dengan derajat serangan akut berat memiliki jumlah eosinofil normal.

Spallarossa, dkk (1995) dalam penelitiannya mendapatkan bahwa terjadi penurunan jumlah eosinofil dalam darah yang bermakna pada saat serangan akut asma jika dibandingkan dengan saat stabil. Penurunan jumlah eosinofil ini lebih jelas terjadi pada pasien yang mengalami infeksi, namun secara statistik tidak terlalu berbeda dengan pasien tanpa infeksi. Hal ini kemungkinan besar disebabkan oleh proses rekrutmen eosinofil ke jaringan paru, dan dibuktikan dengan bilasan bronkoalveolar yang menunjukkan adanya eosinofilia. ${ }^{17}$

Terdapat beberapa hal yang dapat memengaruhi hasil penelitian ini, salah satunya adalah tidak diketahui apakah pasien menderita infeksi parasit, seperti cacing. Infeksi parasit akan menyebabkan peningkatan jumlah eosinofil yang bisa menimbulkan kekeliruan terhadap peningkatan jumlah eosinofil pada pasien asma bronkial. Sementara itu, pemakaian obat-obatan seperti kortikosteroid yang telah atau sedang dilakukan, dapat menekan jumlah leukosit termasuk eosinofil. ${ }^{4,18}$

Selain itu, waktu pemeriksaan darah tepi juga menjadi kendala dalam menentukan jumlah eosinofil dalam darah. Spector, dkk (2011) dalam penelitiannya menyimpulkan bahwa jumlah hitung jenis eosinofil berubah-ubah secara signifikan dalam sehari tanpa alergi pemicu ataupun pola diurnal yang jelas. Dengan demikian, pemeriksaan hitung jenis eosinofil yang dilakukan terhadap penderita asma perlu dilakukan beberapa kali dikarenakan jumlah eosinofil yang berfluktuasi sepanjang hari. ${ }^{19}$

Dilain pihak, Douwes, dkk (2002) berpendapat bahwa terdapat asma yang tidak melalui mekanisme yang melibatkan eosinofil, dikenal sebagai non-eosinophilic asthma, tetapi berhubungan dengan respon neutrofil. Paparan terhadap endotoksin bakteri, polusi udara, dan juga infeksi virus dapat menjadi pencetus infiltrasi neutrofil pada asma. Apabila penderita mengalami non-eosinophilic asthma, maka pada pemeriksaan darah tepi tidak akan didapatkan peningkatan jumlah eosinofil ataupun keadaan eosinofilia. $^{20}$

\section{KESIMPULAN}

Berdasarkan penelitian yang dilakukan terhadap rekam medik pasien asma bronkial yang dirawat inap di Bangsal Paru RSUP Dr. M. Djamil Padang periode Januari 2010 sampai Desember 2011, dapat diambil beberapa kesimpulan yaitu :

1. Perempuan lebih banyak menderita asma bronkial dibandingkan laki-laki

2. Serangan akut asma bronkial paling banyak terjadi pada kelompok umur 40 sampai 49 tahun.

3. Jumlah eosinofil darah tepi pada penderita asma bronkial lebih banyak dibawah $40 / \mathrm{mm}^{3}$.

4. Tidak ditemukan penderita asma bronkial dengan jumlah eosinofil lebih dari $400 / \mathrm{mm}^{3}$

\section{DAFTAR RUJUKAN}

1. Moqbel R, Odemuyiwa SO, Lacy P, Adamko DJ. The Human Eosinophil. Dalam: Greer JP,
Foerster J, Rodgers GM, et al, editor. Wintrobe's Clinical Hematology, vol $1,12^{\text {th }}$ ed. Philadelphia: Lippincott Williams \& Wilkins; 2009. hlm. 214-35.

2. Junqueira LC, Carneiro J. Histologi Dasar: Teks dan Atlas. Edisi ke-10. Jakarta: EC; 2007. hlm. 244-45.

3. Ackerman SJ, Butterfield JH. Eosinophilia, Eosinophil-Associated Diseases, and the Hypereosinophilic Syndrome. Dalam Hematology : Basic Principles and Practice, $3^{\text {rd }}$ Ed. United States of America: Churcill Livingstone; 2000.

4. Weller PF. The Immunobiology of Eosinophils. The New England Journal of Medicine. 1991; 324(16): 1110-8. (diunduh 12 April 2012). Tersedia dari: URL: HYPERLINK http://www.nejm.org.

5. Global Initiative for Asthma. Global Strategy for Asthma Management and Prevention. 2011. (diunduh 21 April 2012). Tersedia dari: URL: HYPERLINK: http://www.ginasthma.org.

6. Baratawidjaja KG, Rengganis I. Alergi Dasar. Jakarta: Interna Publishing; 2009.

7. Mason RJ, Broaddus VC, Murray JF, Nadel JA. Murray dan Nadel's Textbook of Respiratory Medicine, vol 1, $4^{\text {th }}$ ed. United States of America: Elsevier Saunders; 2005.

8. Mitchell RN, Kumar V. Penyakit Imunitas. Dalam: Kumar V, Cotran RS, Robbins SL, editor. Buku Ajar Patologi Robbins, vol 1. Edisi ke-7. Jakarta : ECG; 2007

9. Fishman AP, Elias JA, Fishman JA, Grippi MA, Senior RM, Pack Al. Fishman's Pulmonary Diseases and Disorders, vol 1, $4^{\text {th }}$ ed. China: The McGraw-Hill Companies, Inc; 2008.

10. Rosa MS, Pinto AM. Cytokines. Dalam: Burtis CA, Ashwood ER, Bruns DE, editor. Tietz Textbook of Clinical Chemistry and Molecular Diagnostic, $4^{\text {th }}$ ed. United States of America: Elsevier Inc, 649-52; 2006.

11. Darwin E. Imunologi dan Infeksi. Padang : Andalas University Press; 2006.

12. Maitra A, Kumar V. Paru dan Saluran Napas Atas. Dalam: Kumar V, Cotran RS, Robbins SL, editor. Buku Ajar Patologi Robbins, vol 2, ed 7. Jakarta : ECG; 2007. hlm 511-14.

13. Akinbami LJ. Asthma Prevalence, Health Care Use, and Mortality: United States 2005-2009. National Health Statistic Reports. 2011; 32. (diunduh 13 Juni 2012). Tersedia dari: URL: HYPERLINK http://www.cdc.gov.

14. Sihombing $M$, Alwi $Q$, Nainggolan $O$. Faktorfaktor yang Berhubungan dengan Penyakit Asma pada Usia $\geq 10$ Tahun di Indonesi (Analisis Data Riskesdas 2007). Jurnal Respirologi Indonesia. 2010; 30(2): 85-91. (diunduh 15 januari 2013). Tersedia dari: URL: HYPERLINK http://www.jurnalrespirologi.org.

15. National Health Interview Survey. Current Asthma Prevalence Percents by Age. 2009 Lifetime and Current Asthma. 2009. (diakses 15 Januari 2013). Tersedia dari: URL: HYPERLINK http://www.cdc.gov.

16. Oemiati $R$, Sihombing $M$, Qomariah. FaktorFaktor yang Berhubungan dengan Penyakit Asma di Indonesia. Media Litbang Kesehatan vol. XX no. 1; 2010. hlm 41-49.

17. Spallarossa D, Sacco O, Girosi D, Rossi GA. Blood Eosinophil Counts and Arterial Oxygen 
Tension in Acute Asthma. Archieve of Disease in Childhood. 1995; 73: 333-7. (diunduh 27 Desember 2012). Tersedia dari: URL: HYPERLINK http://www.ncbi.nlm.nih.gov.

18. Altman LC, Hill JS, Hairfield WM, Mullarkey MF. Effects of Corticosteroids on Eosinophils Chemotaxis and Adherence. The Journal of Clinical Investigation. 1981; 67(1): 28-36. (diunduh 30 Desember 2012). Tersedia dari: URL:HYPERLINK http://www.jci.org.

19. Spector S, Tan R, Malinowski A. Labile Blood Eosinophilia in Asthma. Chest Journal. 2011; 140(4): 214-216. (diunduh 27 Desember 2012). Tersedia dari: URL: HYPERLINK http://journal.publications.chestnet.org.

20. Douwes J, Gibson P, Pekkanen J, Pearce N. Non-eosinophilic Asthma: Importance and Possible Mechanisms. Thorax. 2002; 57: 643-8. (diunduh 21 Desember). Tersedia dari: URL: HYPERLINK http://www.thorax.bmj.com. 